\title{
Potential application of Bacillus amyloliquefaciens EB13 inoculant for improving soil fertility and Citrus sinensis growth
}

\section{Idris Idris*, Yuliar Yuliar}

Microbiology Division, Research Center for Biology, National Research and Innovation Agency (BRIN), Cibinong 16911, West Java, Indonesia

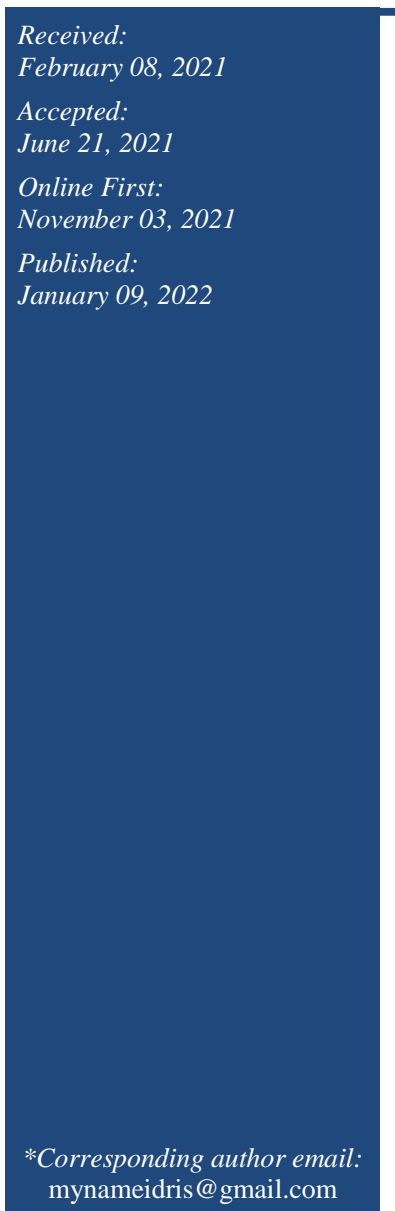

\begin{abstract}
The application of bacterial inoculants to suppress crop diseases and boost crop yields supports sustainable agriculture by reducing the use of chemical fertilizers and pesticides. Bacillus amyloliquefaciens EB13 inoculant was applied to citrus plants (Citrus sinensis) in the field to investigate the effect of strain EB13 treatment on soil fertility and citrus growth in non-sterile conditions. Two years old citrus tree transplanted into the polybag containing $10 \mathrm{~kg}$ soil was inoculated with EB13 culture and placed in the open field for six months. Soil enzyme activities were increased significantly $(\mathrm{P}<0.05)$ by EB13 inoculation, they are acid phosphatase activity (1848.82 to $2450.50 \mu \mathrm{g} \mathrm{p}-\mathrm{NP} / \mathrm{g}$ dry soil $\mathrm{h}$ ), alkaline phosphatase activity (475.15 to $640.98 \mu \mathrm{g} \mathrm{p}-\mathrm{NP} / \mathrm{g}$ dry soil $\mathrm{h}$ ), urease activity (147.89 to $306.55 \mu \mathrm{gNH}_{4}-\mathrm{N} / \mathrm{g}$ dry soil h), and total soil microbial activity (1.85 to $2.77 \mu \mathrm{g}$ fluorescein/g h). Furthermore, the population of bacteria and fungi in the rhizosphere significantly $(\mathrm{P}<0.05)$ was increased by the EB13 inoculation. These improvements supported citrus growth by increasing fruit yield approximately threefold (5.33 to 18.33 fruits/plant). Our finding indicated that Bacillus amyloliquefaciens EB13 was able to associate well with citrus in the non-sterile condition and has a long-term positive effect on soil fertility and citrus growth.
\end{abstract}

Keywords: Bacillus amyloliquefaciens, Biofertilizer, Citrus sinensis, Soil enzymes, Soil fertility

\section{How to cite this:}

Idris I and Yuliar Y, 2022. Potential application of Bacillus amyloliquefaciens EB13 inoculant for improving soil fertility and Citrus sinensis growth. Asian J. Agric. Biol. 2022(1): 202102069. DOI: https://doi.org/10.35495/ajab.2021.02.069

This is an Open Access article distributed under the terms of the Creative Commons Attribution 3.0 License. (https://creativecommons.org/licenses/by/3.0), which permits unrestricted use, distribution, and reproduction in any medium, provided the original work is properly cited.

\section{Introduction}

Chemical fertilizers have been used widely in agriculture to improve soil fertility hence increase crop yield. However, the long-term application of chemical fertilizers entailed the risk that has led to reducing soil quality and the efficacy of chemical fertilizers has been decreasing over time (Savci, 2012). The excessive use of chemical fertilizers in the long-term causes a number of problems, such as the soil degradation, nutrients leaching, reduction of organic matter, and heavy metal contamination (Han et al., 2016; Lin et al., 2019). Because of these concerns, many studies have been conducted to 
develop green fertilizers, including the development of biofertilizers that utilize plant growth-promoting bacteria.

Soil quality is influenced by many factors such as microbial, biochemical, physical, and chemical of soil. The soil microbial activity directly impacts ecosystem stability and fertility. Therefore, a good level of microbial number is essential to maintain the soil quality. The microorganisms and soil enzymes play a key role in nutrient cycling and essential for mineralization, organic matter transformation, and plant nutrients supply in the soil ecosystem. Soil enzyme is commonly used as a sensitive tool to detect changes in the soil ecosystem including fertility and perturbation (Vázquez et al., 2000).

Interaction between plant and bacteria varies and occurs in different ways. The interaction may support plant growth, threatens plant health, or has no effect on the plant. The change of soil condition may alters the way bacteria interact. Several studies reported that Bacillus strains, including Bacillus amyloliquefaciens, Bacillus cereus, and Bacillus subtilis could interact with plants by promoting plant growth and suppressing plant disease (Choudhary and Johri, 2009). Bacillus is a group of bacteria that can be found elsewhere in a large variety of environments (Felske et al., 2004; Pignatelli et al., 2009; Connor et al., 2010).

As a plant growth-promoting rhizobacteria (PGPR), Bacillus strains can solubilize fixed soil $\mathrm{P}$ and increase the availability of inorganic $\mathrm{P}$ to plants thus enhance crop yields, for example $B$. polymyxa, $B$. pumilus, and B. subtilis (Kumar and Narula, 1999; Matos et al., 2017). There are two mechanisms of how PGPR increases plant growth, via direct and indirect mechanism. Direct mechanism occurs by supplying growth factors to plants, such as nutrients (phosphate solubilization and iron mobilization) and hormones (indole acetic acid, cytokinin, and gibberellin). Indirect mechanism occurs by suppressing the plant pathogens and harmful microorganisms (Glick, 2012; Akinrinlola et al., 2018).

The application of bacteria inoculants in the nonsterile condition in field study still encounter a problem. Most of the researches that have been performed in this condition showed less promising on plant response. The bacteria that was introduced could not perform and survive in the field (non-steril soil) because non- sterile soil contains various microorganism species. Then, the introduced bacteria have to compete with others microorganism species in non-sterile soil in order to survive. Therefore, a study to find the suitable PGPR for non-sterile soil conditions is needed. Thus, the objective of our research was to evaluate the effect of Bacillus amyloliquefaciens EB13 inoculant on soil fertility based on soil chemical properties, microorganism population, soil enzymes and microbial activity in non-sterile soil condition. Moreover, this study also investigated the treatment effect on $C$. sinensis growth. This study is important for reducing the use of chemical fertilizer, particularly in citrus crops. In our previous research, this strain showed the ability to produce plant growth hormone and suppress plant disease (Yuliar et al., 2015).

\section{Material and Methods}

\section{Microorganism culture preparation}

B. amyloliquefaciens EB13 was isolated in our previous study, and it was stored in a $20 \%$ glycerol solution at $-70{ }^{\circ} \mathrm{C}$ for further use. A strain of EB13 was pre-cultured overnight with shaking at $30{ }^{\circ} \mathrm{C}$ in the $100 \mathrm{~mL}$ Erlenmeyer flask containing $20 \mathrm{~mL}$ of Luria-Bertani (LB) medium. After that, $1 \%(\mathrm{v} / \mathrm{v})$ of pre-cultured were inoculated into $250 \mathrm{~mL}$ of No.3 medium in $2 \mathrm{~L}$ Erlenmeyer flasks and incubated for 5 days with agitation at $124 \mathrm{rpm}$ and temperature of $30^{\circ} \mathrm{C}$ (Yuliar et al., 2015)

\section{Pot experiments}

Two hundred $\mathrm{mL}$ of $B$. amyloliquefaciens EB13 culture in No.3 medium was initially inoculated into polybag $(25 \mathrm{~cm}$ (d) x $30 \mathrm{~cm}(\mathrm{~h}))$ containing $10 \mathrm{~kg}$ of garden soil and mixed. For the control (without inoculation of strain EB13) $200 \mathrm{~mL}$ of sterilized distilled water was used instead of the inoculant.

$C$. sinensis tree two years old were transplanted to a polybag and placed in open ground. The citrus was grown for about six months (April - September 2019), and watering was done daily. The second and the third month after citrus transplanted, strain EB13 was re-inoculated into the rhizosphere soil in the polybags as same as the first inoculation by adding and mixing. This experiment was performed in quintuplicate for each treatment. Three months after the third inoculation of strain EB13, the citrus height, diameter, soil $\mathrm{pH}$ were measured, and the rhizosphere soil was collected to determine the soil enzymes activity and to monitor the population of bacteria and fungi. 


\section{Soil physicochemical analysis}

The soil $\mathrm{pH}$ was measured using a $\mathrm{pH}$ meter by mixing the soil with distilled water $(1: 2.5(\mathrm{w} / \mathrm{v}))$ prior to the measurement. The soil moisture was determined after drying the soil at $105{ }^{\circ} \mathrm{C}$ for $24 \mathrm{~h}$. The measurement was conducted in duplicate. Soil organic $\mathrm{C}$, total $\mathrm{N}$, total $\mathrm{P}$, available $\mathrm{P}$, and cation exchange capacity (CEC) were conducted by the Indonesian Soil Research Institute with appropriate standard methods.

\section{Soil bacteria and fungi population determination}

Rhizosphere soil was collected from the pots of the citrus tree and 1 gram of soil was put into a test tube with $9 \mathrm{~mL}$ of sterile distilled water then was vortexed. A serial dilution was made to obtain the final dilution desired. One hundred $\mu \mathrm{L}$ of the dilution samples were spread using a glass rod onto Nutrient Agar (NA) plates and Potatoes Dextrose Agar (PDA) plates for monitoring the population of bacteria and fungi respectively. The NA plates and PDA plates were incubated at room temperature for $2-3$ days and $3-5$ days, respectively. The population density of bacteria in NA plates and fungi in PDA plates were counted (colony forming units/g fresh soil) afterward.

\section{Soil enzymes activity assay}

Soil enzyme activities were analyzed in the fresh soil or soil sample that was stored not longer than one week at $4{ }^{\circ} \mathrm{C}$. Urease was assayed as described by McGarity and Myers (1967). The urease activity was expressed as $\mu \mathrm{g}$ of ammonium that was released by one $\mathrm{g}$ of dry weight soil per hour $\left(\mu \mathrm{gNH}_{4}-\mathrm{N} / \mathrm{g}\right.$ dry soil $h$ ). Phosphatase (acid and alkaline) was measured based on the reduction of p-nitrophenyl phosphate (pNPP) following the method described by Tabatabai (1994). Phosphatase activity was defined as $\mu \mathrm{g}$ of $\mathrm{p}$ nitrophenyl (p-NP) was released by one $g$ soil per hour ( $\mu \mathrm{g} \mathrm{p-NP/g}$ dry soil $\mathrm{h}$ ). For total soil microbial activity was measured based on the hydrolysis of fluorescein diacetate (FDA) (Green et al., 2006) with a slight modification (Liu et al., 2019). The soil enzyme assay was analyzed in two replication of samples and one control for each treatment.

\section{$C$. sinensis growth and fruits yield measurement}

The height of the citrus tree was measured using a measuring tape and the diameter of the citrus stem was measured with a caliper. Citrus fruits were counted per plant and reported as the mean of three replications.

\section{Data analysis}

One-way analysis of variance (ANOVA) was applied to examine the effect of inoculant addition on soil enzyme activity and citrus growth. The treatment means were compared using Tukey's test. Significantly different of means were considered at $\mathrm{P}$ $<0.05$.

\section{Results}

\section{Soil physicochemical properties}

The addition of EB13 did not give a significant increase for the total $\mathrm{N}, \mathrm{P}$, and available $\mathrm{P}$, total $\mathrm{P}$, available $\mathrm{P}$ as $\mathrm{P}_{2} \mathrm{O}_{5}$, Cation Exchange Capacity (CEC) between EB13 treatment and control. The soil physicochemical properties were summarized in Table 1.

\section{Bacteria and fungi population number in the rhizosphere soil}

EB13 treatment significantly has a positive effect on bacteria and the fungi population in the soil. Both the total population of bacteria and fungi in the rhizosphere soil inoculated by EB13 significantly was increased compared with un-inoculated soil (control) (Fig. 1A and 1B). The number of bacteria in soil treated with EB13 was increased five-fold ( 40 to $210 \times 107 \mathrm{CFU} / \mathrm{g}$ fresh) and the number of fungal was increased three-fold (7.67 to $20.67 \times 105 \mathrm{CFU} / \mathrm{g}$ fresh soil) than control. The total number of microorganisms in the soil rhizosphere was dominated by bacteria.

Table-1: Physicochemical properties of soil inoculated by B. amyloliquefaciens EB13 and un-inoculated (control) on 6 month after treatment.

\begin{tabular}{|l|c|c|c|c|c|c|c|c|c|}
\hline Treatment & Texture & $\mathbf{p H}(\mathbf{1 : 2 . 5})$ & Msoisture (\%) & $\mathbf{C ~ ( \% )}$ & $\mathbf{N}(\boldsymbol{\%})$ & $\mathbf{C / N}$ & Total (mg/100 g) & Pav (ppm) & $\begin{array}{c}\text { CEC } \\
(\mathbf{c m o l} / \mathbf{k g})\end{array}$ \\
\hline Control & Clay & 5.8 & 34.7 & 3.00 & 0.23 & 13 & 357 & 484 & 19.67 \\
\hline EB13 & Clay & 6.0 & 32.5 & 4.06 & 0.27 & 15 & 366 & 501 & 22.82 \\
\hline
\end{tabular}

$P$ defined as $\mathrm{P}_{2} \mathrm{O}_{5} ; \mathrm{P}$ av = Available $\mathrm{P} ; \mathrm{CEC}=$ Cation Exchange Capacity 


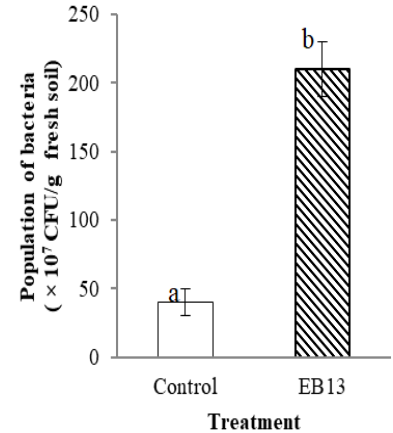

(A)

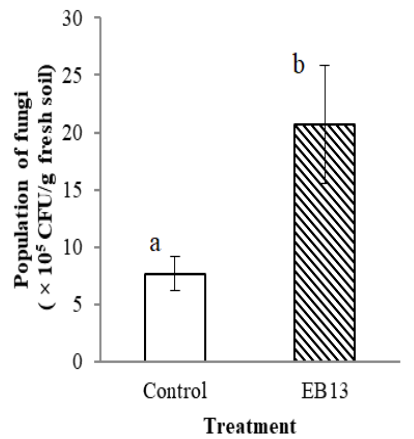

(B)
Figure-1: The population of soil bacteria (A) and fungi (B) in the rhizosphere soil on 6 month after treatment, control (un-inoculated) and EB13 (inoculated by $B$. amyloliquefaciens EB13). Bar with different letter indicates significantly difference $(\mathbf{P}<\mathbf{0 . 0 5})$.

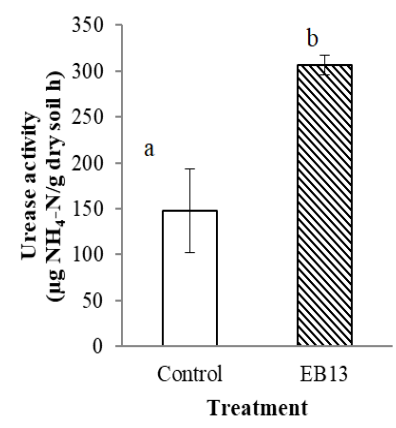

(A)

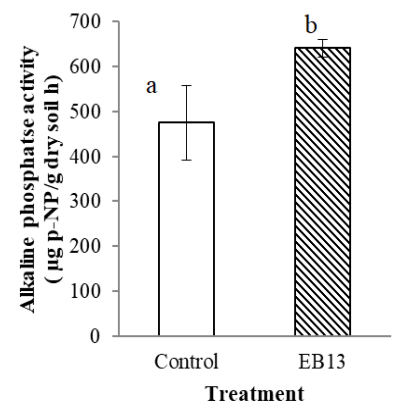

(C)

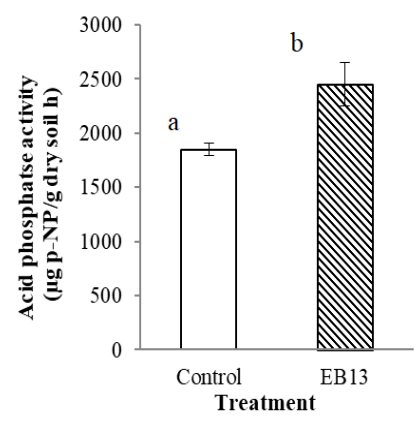

(B)

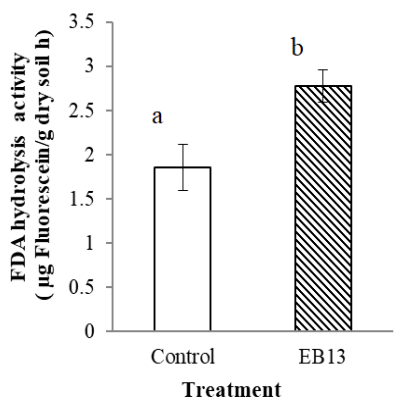

(D)
Figure-2: Soil enzymes activity: (A) urease, (B) acid phosphatase, (C) alkaline phosphatase, and (D) FDA of soil on 6 month after treatment, control (un-inoculated) and EB13 (inoclutaed by B. amyloliquefaciens EB13). Bar with different letter indicates significantly difference $(\mathbf{P}<0.05)$.

\section{Soil enzymes response to $B$. amyloliquefaciens EB13 inoculation}

All of the rhizosphere soil enzymes showed a positive response to the inoculation of EB13. The activity of urease, acid and alkaline phosphatase and hydrolysis of FDA on soil inoculated with EB13 was increased significantly $(\mathrm{P}<0.05)$ compare to uninoculated soil (control) as shown in Fig. 2. In this study, the highest positive response on EB13 inoculation among soil enzymes was given by urease activity (Fig 2A). Urease activity was increased by $100 \%$ (147.89 to $306.55 \mu \mathrm{g}$ NH4-N/g dry soil h), acid phosphatase by $52 \%$ (1848.82 to $2450.50 \mu \mathrm{g} \mathrm{p}-\mathrm{NP} / \mathrm{g}$ dry soil h), and alkaline phosphatase by $34 \%$ (475.15 to $640.98 \mu \mathrm{g} \mathrm{p}-\mathrm{NP} / \mathrm{g}$ dry soil $\mathrm{h}$ ). The phosphatase activity was dominated by acid phosphatase as we can see in Fig. 2B and 2C. FDA hydrolysis reflects the total microbial activity in the soil. The hydrolysis of the FDA was increased (1.85 to $2.77 \mu \mathrm{g}$ fluorescein/g dry soil $h$ ) along with the increase of the microorganism population in soil (Fig. 1 and 2D).

\section{C. sinensis growth and fruits yield}

Inoculation of the strain of EB13 into soil did not give significant effect on citrus height and diameter. However, strain EB13 inoculation resulted in a significant highest $(\mathrm{P}<0.05)$ of citrus fruit production compared with control (without EB13 inoculation). The citrus fruit production was increased by EB13 treatment approximately threefold of control (Table 2).

Table-2: Growth and fruits yield of $C$. sinensis after 6 month treatment, control (un-innoculated) and EB13 (inoculated by B. amyloliquefaciensEB13).

\begin{tabular}{|c|c|c|c|}
\hline Treatment & $\begin{array}{c}\text { Plant height } \\
(\mathbf{c m})\end{array}$ & $\begin{array}{c}\text { Plant diameter } \\
(\mathbf{c m})\end{array}$ & $\begin{array}{c}\text { Total Number of } \\
\text { fruits per plant }\end{array}$ \\
\hline Control & $128.67 \pm 24.7^{\mathrm{a}}$ & $1.76 \pm 0.25^{\mathrm{a}}$ & $5.33 \pm 2.89^{\mathrm{b}}$ \\
\hline EB13 & $145.33 \pm 2.08^{\mathrm{a}}$ & $1.99 \pm 0.45^{\mathrm{a}}$ & $18.33 \pm 2.08^{\mathrm{a}}$ \\
\hline
\end{tabular}

In columns, means followed by the different letter are significantly different $(P<0.05)$.

\section{Discussion}

Soil microorganisms are well-considered to play a role in soil health and fertility. They may affect plant growth and soil enzymes activity. Our study showed that the inoculation of B. amyloliquefaciens EB13 in soil has a positive effect on the below-ground (soil) and the above-ground (plant). In the below-ground, EB13 inoculation changed biochemical, and biological properties. These properties have a strong relationship to soil health and fertility. Then, in the above-ground, EB13 treatment enhanced citrus productivity. 
Our observation in this study showed that there were improvements in soil quality, particularly in biological properties. However, the soil chemical properties such as $\mathrm{C}, \mathrm{N}$, and $\mathrm{P}$ have not showed significant improvement yet. It was assumed that soil chemical properties was not change rapidly and needed a long term of observation to get a significant change (Arévalo-Gardini et al., 2015). Since the experiment was conducted in short term (6 month), probably it was too early to find a significant change on soil chemical properties. Nevertheless, bacterial inoculation could increase the availability of nutrients in soil. Studies was reported that inoculation of Bacillus M-13 and B. amyloliquefaciens Y1 increased total $\mathrm{N}$ and available $\mathrm{P}$ in soil (Canbolat et al., 2006; Jamal et al., 2018).

Our results showed that EB13 could survive and was suitable for field applications. It was indicated by the increasing of soil bacterial population after the treatment. Furthermore, the addition of EB13 also promotes the fungi population in the soil. It can be assumed that EB13 can promote the increase of soil microorganism population by providing the amount of available nutrients which is important for soil microorganism growth besides plants. Moreover, EB13 able to suppress pathogens as reported in our previous study. Therefore, it could be suggested that EB13 able to create a favorable conditions for beneficial microorganisms, hence increased their population (Soohee and Kim, 2005).

The increase of soil microorganism population in line with the increase of soil enzymes activity, particularly urease, acid and alkaline phosphatase. Enzymes in soil mainly were produced by microorganisms. Therefore, increasing of microorganism population bring to the increasing soil enzymes activity. The increase of those enzymes in soil was suggested by EB13 inoculant contribution. This result was supported by several studies that have been reported. B. amyloliquefaciens was reported to produce urease, acid and alkaline phophatase (Matos et al., 2017; Meng et al., 2019; Tepe et al., 2019). Soil enzymes take place in many reactions in soils, including nutrients cycling, organic residues decomposition, organic matter formation, and soil structure (Egamberdieva et al., 2010). Therefore, it was expected that increase of urease, acid and alkaline phosphatase activity would increase available $\mathrm{N}$ and $\mathrm{P}$ resulted from nutrient cycling or decomposition process in soil.

Based on the result of this study, there was an improvement in soil quality as indicated by the increase of the total microbial activity in soil after EB13 inoculation. Total microbial activity was the sum of the physiological activities of all the microorganisms in a given soil sample. Total microbial activity was determined by the hydrolysis of fluorescein diacetate method. Soil enzymes activity including fluorescein diacetate (FDA) hydrolysis activity could be used as an indicator of the state of soil quality because they give a quick response to environmental changes compare to other soil properties (Aseri and Tarafdar, 2006; Henry, 2012).

In the above-ground, $C$. sinensis plant growth, particularly in fruits yield. Fruits production in plants has a strong relationship with nutrition availability (e.g. phosphorus and carbon) and plant growth regulator (e.g. hormone and siderophore) in the soil (Furtak and Gajda, 2018). Those can be provided by beneficial microorganism activities in soil. The same result has been reported that the application of $B$. amyloliquefaciens $\mathrm{Y} 1$ promotes pepper plant growth as the increase of the total number of flowers compared to the un-inoculated plant (control) (Jamal et al., 2018). Moreover, fruit production in citrus plants related to the total number of soil microorganisms. Ghagare et al. (2018) reported that the highest bacteria and the fungal number was found in the highest yielding citrus rhizosphere soil and conversely. The same results also was found in this study. The inoculation of EB13 in soil showed a higher fruits yield with a higher total number of bacteria and fungi than un-inoculated (control).

All of our finding in this study is in agreement with the previous report which showed $B$. amyloliquefaciens improved plant growth and soil enzymes activity (Soohee and Kim, 2005; Gowtham et al., 2018; Kang et al., 2015). B. amyloliquefaciens was reported as one of the endophytic bacteria that was found in the citrus plant. This bacteria plays a role as a biocontrol agent and also can promote plant growth. B. amyloliquefaciens was characterized by indole acetic acid (IAA) production, secretion of hydrolytic enzymes, phosphate solubilization, and antibiosis against fungi and bacteria of plant pathogens (Yuliar, 2015; Soares et al., 2016).

\section{Conclusion}

The EB13 inoculant significantly increased soil enzyme activities, such as phosphatase activity 
(1848.82 to $2450.50 \mu \mathrm{g} \mathrm{p-NP/g}$ dry soil h), alkaline phosphatase activity (475.15 to $640.98 \mu \mathrm{g}$ p-NP/g dry soil h), urease activity (147.89 to $306.55 \mu \mathrm{gNH} 4-\mathrm{N} / \mathrm{g}$ dry soil $\mathrm{h}$ ), and total soil microbial activity (1.85 to $2.77 \mu \mathrm{g}$ fluorescein $/ \mathrm{g} \mathrm{h}$ ). Furthermore, the EB13 inoculant significantly increased the population of bacteria and fungi in the rhizosphere. These improvements supported citrus growth by increasing fruits yield approximately threefold (5.33 to 18.33 fruits/plant). Our finding indicated that Bacillus amyloliquefaciens EB13 was able to associate well with $C$. sinensis in the non-sterile condition and considerable to be used for improving citrus fruits production.

\section{Disclaimer: None.}

\section{Conflict of Interest: None.}

Source of Funding: This study was partially supported by DIPA thematic project of Research Center for Biology, Indonesian Institute of Sciences (LIPI).

\section{References}

Akinrinlola RJ, Yuen GY, Drijber RA and Adesemoye AO, 2018. Evaluation of Bacillus strains for plant growth promotion and predictability of efficacy by in vitro physiological traits, Int. J. Microbiol. 1-11.

Arévalo-Gardini E, Canto M, Alegre J, Loli O, Julca A and Baligar V, 2015. Changes in Soil Physical and Chemical Properties in Long Term Improved Natural and Traditional Agroforestry Management Systems of Cacao Genotypes in Peruvian Amazon. PLOS ONE 10(7): e0132147. doi: 10.1371/journal.pone.0132147

Aseri GK and Tarafdar JC, 2006. Fluorescein diacetate: a potential biological indicator for arid soils. Arid Land Res. Manag. 20(2):87-99.

Canbolat MY, Bilen S, Çakmakçı, R, Şahin F and Aydin A, 2006. Effect of plant growth-promoting bacteria and soil compaction on barley seedling growth, nutrient uptake, soil properties and rhizosphere microflora. Biol. Fertil. Soils. 42:350-357.

Choudhary DK and Johri BN, 2009. Interaction of Bacillus spp. and plants -with special reference to induced systemic resistance (ISR). Microbiol. Res. 164:493-513.

Connor N, Sikorski, Rooney AP, Kopac S, Koeppel AF, Burger A, Cole SG, Perry EB, Krizanc D,
Field NC, Slaton M and Cohan FM, 2010. Ecology of speciation in the genus Bacillus. Appl. Environ. Microbiol. 76:1349-1358.

Egamberdieva D, Renella G, Wirth S and Islam R, 2010. Enzyme Activities in the Rhizosphere of Plants. In: Shukla G, Varma A, editors. Soil Enzymology. Soil Biology, 22. Springer, Berlin, Heidelberg; p. 149-166.

Felske ADM, Tzeneva V, Heyrman J, Langeveld MA, Akkermana ADL and De Vos P, 2004. Isolation and biodiversity of hitherto undescribed soil bacteria related to Bacillus niacini. Microb. Ecol. 48:111-119.

Furtak K and Gajda AM, 2018. Activity and variety of soil microorganisms depending on the diversity of the soil tillage system. In a Oliveira, editor, Sustainability of agroecosystems. Croatia: IntechOpen; p. 45-62.

Ghagare RB, Kuchanwar OD and Deshmukh S, 2018. Rhizosphore Bacillus diversity vis-à-vis fruit yield of citrus. Annals Plant Soil Res. 19(4):438-40.

Glick BR, 2012. Review: Plant Growth-Promoting Bacteria: Mechanisms and Applications. Scientifica. 2012, Article ID 963401

Gowtham HG, Murali M, Singh SB, Lakshmeesha TR, Murthy KN, Amrutheshb KN and Niranjanaa SR, 2018. Plant growth promoting rhizobacteria Bacillus amyloliquefaciens improves plant growth and induces resistance in chilli against anthracnose disease. Biol. Control. 126:209-217.

Green VS, Stott DE and Diack M, 2006. Assay for fluorescein diacetate hydrolytic activity: optimization for soil sample soil. Biol. Biochem. 38(4):693-70.

Han SH, An JY, Hwang J, Kim SB and Park BB, 2016. The effects of organic manure and chemical fertilizer on the growth and nutrient concentrations of yellow poplar (Liriodendron tulipifera Lin.) in a nursery system. Forest. Sci. and Technol. 2(3):137-143.

Henry HAL, 2012. Soil extracellular enzyme dynamics in a changing climate. Soil Biol. Biochem. 47:53-59.

Jamal Q, Seong LY, Deok JH and Young KK, 2018. Effect of plant growth-promoting bacteria Bacillus amylliquefaciens Y1 on soil properties, pepper seedling growth, rhizosphere bacterial flora and soil enzymes. Plant Prot. Sci. 54:129137.

Kang SM, Radhakrishnan R, Lee KE, You YH, Ko 
JH, Kim JH and Lee IJ, 2015. Mechanism of plant growth promotion elicited by Bacillus sp. LKE 15 in oriental melon. Acta Agriculturae Scandinavica, Section B-Soil \& Plant Science. 65(7):637-647.

Kumar V and Narula N, 1999. Solubilization of inorganic phosphates and growth emergence of wheat as affected by Azotobacter chroococcum mutants. Biol. Fertil. Soils. 28:301-305.

Lin $\mathrm{W}$, Lin $\mathrm{M}$, Zhou H, Wu H, Li Z and Lin W, 2019. The effects of chemical and organic fertilizer usage on rhizosphere soil in tea orchards. PLoS One. 14(5):e0217018.

Liu H, Khan MY, Carvalhais LC, Delgado-Baquerizo M, Yan L, Crawford M, Dennis PG, Singh B and Schenk PM, 2019. Soil amendments with ethylene precursor alleviate negative impacts of salinity on soil microbial properties and productivity. Sci Rep. 9:6892.

Matos ADM, Gomes ICP, Nietsche S, Xavier AA, Gomes WS, Neto JADS and Pereira MCT, 2017. Phosphate solubilization by endophytic bacteria isolated from banana trees. Anais da Academia Brasileira de Ciências. 89(4):2945-2954.

McGarity JW and Myers MG, 1967. A survey of urease activity in soils from Northern New South Wales. Plant Soil. 27:217-238.

Meng D, Jiang W, Li J, Huang L, Zhai L, Zhang L, Zhengbing G, Cai Y and Liao X, 2019. An alkaline phosphatase from Bacillus amyloliquefaciens YP6 of new application in biodegradation of five broad-spectrum organophosphorus pesticides. J. Environ. Sci. Health, Part B. 54:4,336-343.

Pignatelli M, Moya A and Tamames J, 2009. EnvDB, a database for describing the environmental distribution of prokaryotic taxa. Environ. Microbiol. Rep. 1:191-197.

Savci S, 2012. An agricultural pollutant: chemical fertilizer. Int. J. Environ. Sci. Dev. 3:77-80.

Soares MA, Li H, Bergen M, da Silva JM, Kowalski KP and Whiteet JF, 2016. Functional role of an endophytic Bacillus amyloliquefaciens in enhancing growth and disease protection of invasive english ivy (Hedera helix L.). Plant Soil. 405:107-123.

Soohee C and Kim SD, 2005. Biological control of phytopathogenic fungi by Bacillus amyloliquefaciens 7079; supression sates are better than popular chemical fungicides. J. Microbiol. Biotechnol. 15(5):1011-1021.

Tabatabai MA, 1994. Soil enzymes. In Mickelson $\mathrm{SH}$, editor. Methods of Soil Analysis, Part 2: Microbiological and Biochemical Properties. Madison, WI, USA: Soil Science Society of America. pp. 775-833.

Tepe M, Arslan Ş, Koralay T and Mercan Doğan N, 2019. Precipitation and characterization of $\mathrm{CaCO} 3$ of Bacillus amyloliquefaciens U17 strain producing urease and carbonic anhydrase. Turk J. Biol. = Turk Biyoloji Dergisi. 2019;43(3):198208.

Vázquez MM, César S, Azcón R and Barea JM, 2000. Interactions between arbuscular mycorrhizal fungi and other microbial inoculants (Azospirillum, Pseudomonas, Trichoderma) and their effects on microbial population and enzyme activities in the rhizosphere of maize plants, Appl. Soil Ecol. 15(3):261-272.

Yuliar, Toyota K and Yokota K, 2015. Characterization of possible bacterial biocontrol agents isolated form various plants in Indonesia against bacterial wilt and damping-off of tomato. Soil Microorganisms. 69(1):39-47.

Yuliar, 2015. Influence of saline tolerant BCA concortia on growth of rice. Int. J. Adv. Res. Biol. Sci. 2(8):85-89.

\section{Contribution of Authors}

Idris I: Data collection and analysis, literature review and manuscript writing

Yuliar Y: Designed and supervised the study, data analysis and manuscript writing 